\title{
Deteksi Sinyal : Overview Model Parametrik menggunakan Kriteria Neyman-Pearson
}

\author{
FIKY YOSEF SURATMAN, ALOYSIUS ADYA PRAMUDITA, DHARU ARSENO
}

School of Electrical Engineering Telkom University

Email: fysuratman@telkomuniversity.ac.id

Received 11 September 2018 | Revised 26 September 2018 | Accepted 20 Oktober 2018

\begin{abstract}
ABSTRAK
Deteksi sinyal banyak diimplementasikan dalam sistem pengolahan sinyal yang sangat kompleks. Sebagai contoh digunakan pada sub sistem pengolahan sinyal radar pengintai yang berfungsi untuk deteksi dan pelacakan target. Salah satu implementasi terbaru dari deteksi sinyal adalah untuk fungsi spectrum sensing pada Cognitive Radio. Deteksi sinyal dapat didefinisikan sebagai binary hypothesis testing, yaitu memutuskan satu dari dua keadaan: hanya derau atau tidak ada sinyal (null hypothesis), dan ada sinyal (alternative hypothesis). Teori deteksi sinyal merupakan bidang yang cukup luas, sehingga paper ini fokus pada pendekatan parametrik dengan Teorema Neyman-Pearson. Kedua hypothesis dimodelkan dengan variabel acak dengan distribusi rapat kemungkinan yang sama tetapi mempunyai parameter yang berbeda. Ditunjukkan penurunan test statistic untuk dua skenario, yaitu distribusi dengan diketahui sebagian dan diketahui penuh. Bagian simulasi menunjukkan kinerja detektor sinyal secara analitis mempunyai hasil yang serupa dengan simulasi Monte Carlo.
\end{abstract}

Kata kunci: deteksi sinyal, Neyman-Pearson, hypothesis testing, spectrum sensing, radar.

\section{ABSTRACT}

Signal detection has been used in many sophisticated signal processing systems, such as for signal processing in surveillance radar which is to detect and to track a radar target. Recently, signal detection is widely used for spectrum sensing in Cognitive Radio. Signal detection is a binary hypothesis testing problem which is to choose one out of two conditions, i.e., noise only or signal absence (null hypothesis), and signal presence (alternative hypothesis). Since signal detection theory is a wide area, this paper only focuses on parametric approach using Neyman-Pearson theorem. The two hypotheses are modeled by random variables having the same distribution but different parameters. The derivations of test statistics (detectors) are shown for two scenarios, i.e., partially known and perfectly known distributions. Analytical results and Monte Carlo simulations of the derived detectors show similar performances.

Keywords: signal detection, Neyman-Pearson, hypothesis testing, spectrum sensing, radar. 
Deteksi Sinyal: Overview untuk Model Parametrik menggunakan Kriteria Neyman-Pearson

\section{PENDAHULUAN}

Teori deteksi sinyal memiliki peran yang fundamental dalam desain sistem pengolahan sinyal untuk membuat keputusan maupun ekstraksi informasi seperti pada Radar, Sonar, Sistem Komunikasi, Speech, Image Processing, Biomedicine, Control dan Seismology (Kay, 1998). Sistem-sistem tersebut memiliki kesamaan tujuan, yaitu membuat keputusan (decision making) ketika sebuah event of interest terjadi, dan kemudian menentukan informasi lebih jauh tentang event tersebut. Decision making, merupakan fokus utama yang dibahas pada paper ini, yang secara luas biasa disebut dengan teori deteksi (detection theory). Dalam hal ini event of interest adalah keberadaan sinyal informasi, sehingga disebut dengan teori deteksi sinyal (signal detection theory).

Contoh penerapan deteksi sinyal adalah pada radar pengintai dalam menentukan ada atau tidaknya target pesawat yang sedang terbang pada jarak tertentu. Untuk mencapai tujuan tersebut, radar mentransmisikan pulsa elektromagnetik yang dapat dipantulkan kembali (echo) dan kemudian diterima oleh perangkat penerima radar (Richards, 2014). Jika target pesawat ada, sinyal terima pada radar terdiri dari sinyal echo dan derau akibat radiasi sekitar dan perangkat elektronik penerima. Sebaliknya, jika tidak ada target maka hanya derau yang ada pada perangkat penerima radar. Oleh sebab itu, penerima radar membutuhkan perangkat detektor sinyal untuk memutuskan salah satu dari dua keadaan tersebut.

Aplikasi terkini yang membutuhkan penerapan deteksi sinyal adalah spectrum sensing pada Cognitive Radio (CR), atau lebih tepatnya disebut Dynamic Spectrum Access (DNA). DNA dianggap sebagai solusi dimasa depan untuk meningkatkan utilisasi spectrum band nirkabel yang saat ini cukup rendah akibat manajemen spektrum dengan command and contro/model (Hossain, 2009). Pada konsep DNA, Primary User (PU) sebagai pemegang lisensi penggunaan spektrum mempunyai prioritas tertinggi dalam menggunakan sebuah spectrum band, sedangkan Secondary User (SU) yang tak berlisensi dapat menggunakan spectrum band apabila tidak sedang digunakan oleh PU. Oleh sebab itu SU memerlukan fungsi spectrum sensing untuk mengetahui apakah sebuah spectrum band sedang digunakan oleh PU atau tidak (Axell, 2012). SU akan menerima sinyal transmisi dari PU plus derau saat sebuah spectrum band sedang dipakai, sedangkan derau saja saat spectrum band tidak sedang dipakai oleh Primary User.

Paper ini tidak ditujukan untuk memberikan kebaruan dalam teori deteksi sinyal. Tetapi dapat dijadikan sebagai overview atau pengenalan teori deteksi sinyal dengan pendekatan parametrik menggunakan teorema Neyman-Pearson. Materi pada paper dapat digunakan oleh para mahasiswa/peneliti yang mempunyai ketertarikan riset pada pengolahan sinyal radar maupun komunikasi nirkabel. Paper ini juga diharapkan dapat menjadi solusi bagi para mahasiswa/peneliti yang mengalami kesulitan untuk menterjemahkan aspek teoritis deteksi sinyal ke dalam algoritma perangkat lunak baik untuk implementasi maupun simulasi. Paper dilengkapi lampiran secara terpisah sebagai suplemen yang dapat diminta melalui email ke penulis pertama.

\section{VARIABEL ACAK}

Konsep mengenai variabel acak sangat penting dalam teori deteksi sinyal, khususnya untuk metode yang menggunakan model parametrik. Pada bagian ini akan dijelaskan secara singkat konsep variabel acak terutama yang berhubungan dengan fungsi distribusi. 
Variabel acak (random variable) adalah fungsi yang memetakan luaran dari eksperimen acak ke bilangan real (Garcia, 1994). Dalam kasus deteksi sinyal, setiap sampel dari sinyal yang diobservasi adalah sebuah variabel acak. Sebagai contoh, jika sebuah penerima melakukan observasi dengan melakukan sampling sebanyak $N$ sampel yang dinyatakan dengan sebuah urutan sampel acak $\boldsymbol{x}_{\boldsymbol{N}}$, dimana :

$$
\boldsymbol{x}_{\boldsymbol{N}}=[x(0) x(1) \ldots x(N-1)],
$$

maka setiap sampel $x(i)$ dapat dianggap sebuah realisasi dari sebuah variabel acak $X$. Karena $x(i)$ kontinyu pada rentang $-\infty<x(i)<\infty, X$ adalah variabel acak kontinyu.

Hal yang paling penting dalam karakterisasi variabel acak adalah menentukan probabilitas harga-harga yang mungkin diambil oleh variabel acak tersebut. Pada variabel acak kontinyu, probabilitas tersebut dinyatakan dengan fungsi distribusi kumulatif atau disebut Cumulative Distribution Function (CDF). CDF $F(x)$ dari sebuah variabel acak $X$ dapat didefinisikan sebagai probabilitas kejadian $\{X \leq x\}$, secara formal dapat dituliskan sebagai fungsi berikut :

$$
F(x)=P(X \leq x)
$$

dimana $P(A)$ menyatakan probabilitas kejadian $A$. Fungsi lain sebagai alternatif untuk karakterisasi sebuah variabel acak adalah fungsi rapat kemungkinan, atau Probability Density Function (PDF), yang didefinisikan sebagai turunan dari CDF.

$$
p(x)=\frac{d F(x)}{d x}
$$

PDF menyatakan kemungkinan variabel acak $X$ berada pada interval di sekitar $x$, yaitu $x<X \leq x+h$, dimana $h$ sangat kecil. Sehingga, untuk menyatakan bahwa probabilitas sebuah sampel dari sinyal observasi mempunyai harga pada rentang $(a, b)$ dapat dinyatakan dengan Persamaan (3).

$$
P(a \leq X \leq b)=\int_{a}^{b} p(x) d x=F(b)-F(a) .
$$

PDF untuk sebuah urutan acak $x_{N}$ yang melibatkan sejumlah $N$ variabel acak disebut joint Probabiltiy Density Function (joint PDF) yang dinyatakan dengan simbol $p\left(\boldsymbol{x}_{N}\right)$. Untuk kasus dimana antar sampel bebas (independent), joint PDF merupakan perkalian masing-masing (marginal) PDF dari setiap variabel acak sampel, yaitu :

$$
p\left(\boldsymbol{x}_{N}\right)=p_{X}(x(0)) p_{X}(x(1)) \ldots p_{X}(x(N))
$$

Contoh PDF yang sering dipergunakan adalah PDF Gaussian (biasa disebut juga PDF normal). PDF Gaussian untuk variabel acak $X$ didefinisikan sebagai Persamaan (5).

$$
p(x)=\frac{1}{\sqrt{2 \pi \sigma^{2}}} \exp \left[-\frac{1}{2 \sigma^{2}}(x-\mu)^{2}\right]
$$

yang ditentukan oleh dua parameter yaitu mean $\mu$ dan variansi $\sigma^{2}$. Pada paper ini akan digunakan simbol seperti pada Persamaan (6).

$$
x \sim N\left(\mu, \sigma^{2}\right),
$$


Untuk menyatakan bahwa variabel acak $X$ terdistribusi (PDF) Gaussian dengan mean $\mu$ dan variansi $\sigma^{2}$. Berdasarkan Persamaan (4), joint PDF urutan acak $\boldsymbol{x}_{\boldsymbol{N}}$ dengan masing-masing sampel $x(i)$ terdistribusi Gaussian dengan parameter mean dan variansi yang sama, $x(i) \sim N\left(\mu, \sigma^{2}\right), i=1,2, \ldots, N$, dan saling bebas antar sampel dapat dinyatakan dengan Persamaan (7).

$$
p\left(\boldsymbol{x}_{N} ; \mu, \sigma^{2}\right)=\frac{1}{\left(2 \pi \sigma^{2}\right)^{N / 2}} \exp \left[-\frac{1}{2 \sigma^{2}} \sum_{i=0}^{N-1}(x(i)-\mu)^{2}\right] .
$$

\section{TEORI DETEKSI SINYAL DENGAN MODEL PARAMETRIK}

\subsection{Binary Hypothesis Testing}

Metode statistik yang paling fundamental dalam teori deteksi sinyal adalah hypothesis testing (Poor, 1988). Untuk memahami hypothesis testing, ada baiknya meninjau sebuah contoh kasus deteksi sinyal pada radar pengintai (surveillence radar) (Richard, 2014). Sistem radar pengintai dirancang untuk menentukan ada tidaknya target pesawat pada daerah jangkauan radar. Untuk mencapai tujuan tersebut antena pengirim radar mengirimkan gelombang elektromagnetik yang kemudian akan dipantulkan kembali (sinyal echo) sebagian menuju antena penerima radar apabila ada target pesawat yang bergerak. Pada kondisi tersebut, antena penerima radar tidak hanya menerima sinyal echo tetapi ditambah dengan derau (noise) yang pasti ada di setiap perangkat penerima. Sedangkan saat tidak ada target maka radar hanya akan mendeteksi derau. Pada kasus radar tersebut terdapat dua hypothesis, yaitu saat target tidak ada (derau saja) dan saat target ada (sinyal echo dan derau). Kedua hypothesis tersebut dapat ditulis sebagai berikut :

$$
\begin{aligned}
& H_{0} \text { : Target tidak ada (derau) } \\
& H_{1} \text { : Target ada (sinyal echo }+ \text { derau), }
\end{aligned}
$$

Dimana $H_{0}$ disebut dengan null hypothesis dan $H_{1}$ disebut dengan alternative hypothesis. Karena terdapat dua kondisi (binary) yang akan dipilih, masalah deteksi sinyal disebut juga binary hypothesis testing. Lebih jauh, jika sebuah penerima melakukan observasi dengan melakukan sampling sebanyak $N$ sampel yang dinyatakan dengan sebuah urutan sampel acak $\boldsymbol{x}_{\boldsymbol{N}}=\left[\begin{array}{lll}x(0) & x(1) \ldots x(N-1)\end{array}\right]$, maka kedua hypothesis dapat dituliskan juga sebagai Persamaan (8).

$$
\begin{aligned}
& H_{0}: x(n)=w(n) \\
& H_{1}: x(n)=s(n)+w(n), \quad n=0,1,2, \ldots, N-1
\end{aligned}
$$

Dimana $x(n)$ menyatakan sinyal yang diterima oleh antena penerima, $s(n)$ adalah sinyal echo dan $w(n)$ adalah derau. Berdasarkan sinyal terima $x(n)$ maka pendeteksi sinyal (detektor) akan menentukan apakah $x(n)$ mengandung $s(n)$ atau tidak.

Jika diasumsikan bahwa data $\boldsymbol{x}_{\boldsymbol{N}}$ berasal dari distribusi (PDF) tertentu, model parametrik dapat digunakan pada deteksi sinyal. Pada kasus ini, sensor atau antena diasumsikan menerima sinyal acak yang mengikuti famili distribusi yang sama dan dapat didefinisikan dengan menggunakan sejumlah parameter distribusi yang terbatas (finite), baik pada null hypothesis $H_{0}$ maupun pada alternative hypothesis $H_{1}$. Sehingga, masalah binary hypothesis testing pada model parametrik secara formal dapat dinyatakan dengan Persamaan (9).

$$
\begin{aligned}
& H_{0}: p_{0}\left(\boldsymbol{x}_{\boldsymbol{N}} ; \boldsymbol{\theta}_{\mathbf{0}}\right) \\
& H_{1}: p_{1}\left(\boldsymbol{x}_{\boldsymbol{N}} ; \boldsymbol{\theta}_{\mathbf{1}}\right)
\end{aligned}
$$


Dimana $p_{i}\left(\boldsymbol{x}_{\boldsymbol{N}} ; \boldsymbol{\theta}_{\boldsymbol{i}}\right)$ menyatakan joint PDF dari $\boldsymbol{x}_{\boldsymbol{N}}$ saat $H_{i}, i=0,1$, dengan parameter $\boldsymbol{\theta}_{\boldsymbol{i}}, i=0,1$. Untuk kasus joint PDF Gaussian, maka $p_{i}\left(\boldsymbol{x}_{N} ; \boldsymbol{\theta}_{\boldsymbol{i}}\right)$ mengikuti persamaan (7), dimana mean dan variansi $\left(\mu_{i}, \sigma_{i}^{2}\right)$ adalah fungsi dari parameter $\boldsymbol{\theta}_{\boldsymbol{i}}$.

Pada beberapa aplikasi, $\boldsymbol{x}_{\boldsymbol{N}}$ tidak dapat diasumsikan berasal dari distribusi tertentu sehingga model non-parametrik untuk binary hypothesis testing harus digunakan. Deteksi sinyal model non-parametrik di luar cakupan paper ini, dan pembaca dapat mengacu pada (Gibson, 1996).

Berdasarkan sinyal yang diterima, detektor akan membuat keputusan (decision) $D_{i}, i=0,1$, di antara dua hypothesis yang ada. Dalam membuat keputusan tersebut ada empat kondisi yang mungkin terjadi seperti yang terlihat pada Tabel 1 . Keputusan dapat berarti betul (sesuai dengan kenyataan), dan dapat berarti salah (tidak sesuai dengan kenyataan).

Tabel 1. Empat Kondisi yang Mungkin saat Detektor Memutuskan

\begin{tabular}{|c|c|c|}
\hline \multirow{2}{*}{ Kenyataan } & \multicolumn{2}{|c|}{ Keputusan } \\
\cline { 2 - 3 } & Tidak ada sinyal $\left(D_{0}\right)$ & Ada sinyal $\left(D_{1}\right)$ \\
\hline Tidak ada sinyal $\left(H_{0}\right.$ true $)$ & Keputusan betul & Keputusan salah \\
& dengan probabilitas & (false alarm) dengan \\
& $\mathrm{P}\left(D_{0} / H_{0}\right)$ & probabilitas $\mathrm{P}\left(D_{1} / H_{0}\right)$ \\
\hline Ada sinyal $\left(H_{1}\right.$ true $)$ & Keputusan salah & Keputusan betul \\
& $($ miss detection $)$ & dengan probabilitas \\
& dengan probabilitas & $\mathrm{P}\left(D_{1} / H_{1}\right)$ \\
& $\mathrm{P}\left(D_{0} / H_{1}\right)$ & \\
\hline
\end{tabular}

Ukuran kinerja dari detektor biasanya dinyatakan dengan probabilitas kondisi masing-masing akan terjadi yaitu: $\mathrm{P}\left(D_{0} / H_{0}\right), \mathrm{P}\left(D_{1} / H_{0}\right), \mathrm{P}\left(D_{0} / H_{1}\right)$, dan $\mathrm{P}\left(D_{1} / H_{1}\right)$, dimana $\mathrm{P}\left(D_{0} / H_{0}\right)+\mathrm{P}\left(D_{1} / H_{0}\right)$ $=1$ dan $\mathrm{P}\left(D_{0} / H_{1}\right)+\mathrm{P}\left(D_{1} / H_{1}\right)=1$.

\subsection{Detektor Sinyal}

Terdapat banyak pendekatan yang dapat dipilih untuk menentukan detektor sinyal pada binary hypothesis testing. Dua di antaranya yang populer pada model parametrik adalah menggunakan kriteria Bayes (Bayes criterion) dan kriteria Neyman-Pearson (Neyman-Pearson Criterion) (Poor, 1988). Dengan pertimbangan bahwa kriteria Neyman-Pearson (NP) lebih banyak digunakan dibanding kriteria Bayes pada konsep deteksi sinyal radar dan spectrum sensing, maka fokus dari paper ini adalah penentuan detektor sinyal menggunakan kriteria NP. Selain itu kesulitan dalam menentukan cost-function yang sesuai dengan skenario yang ada dan tidak diketahuinya probabilitas a-priori (a-priori probability) untuk kemunculan sinyal, menjadi alasan mengapa kriteria Bayes relatif jarang digunakan dibanding kriteria NP (Kay, 1998).

\section{Kriteria Neyman-Pearson}

Jika diasumsikan penerima melakukan observasi dengan melakuan sampling urutan acak $\boldsymbol{x}_{\boldsymbol{N}}=$ $[x(0) x(1) \ldots x(N-1)]$ dan $T\left(\boldsymbol{x}_{N}\right)$ adalah test statistic yang merupakan fungsi dari data hasil sampling $\boldsymbol{x}_{N}$, maka detektor generik dapat dinyatakan sebagai berikut :

$$
T\left(\boldsymbol{x}_{\boldsymbol{N}}\right) \begin{cases}>\tau, & \text { Terima } H_{1}\left(D_{1}\right) \\ <\tau, & \text { Terima } H_{0}\left(D_{0}\right)\end{cases}
$$


Dimana $\tau$ menyatakan threshold yang memisahkan daerah keputusan $R_{0}$ (terima $H_{0}$ ) dan $R_{1}$ (terima $\left.H_{1}\right)$. Karena $T\left(\boldsymbol{x}_{N}\right)$ adalah fungsi dari variabel-variabel acak sampel, maka $T\left(\boldsymbol{x}_{N}\right)$ juga merupakan variabel acak yang mempunyai PDF.

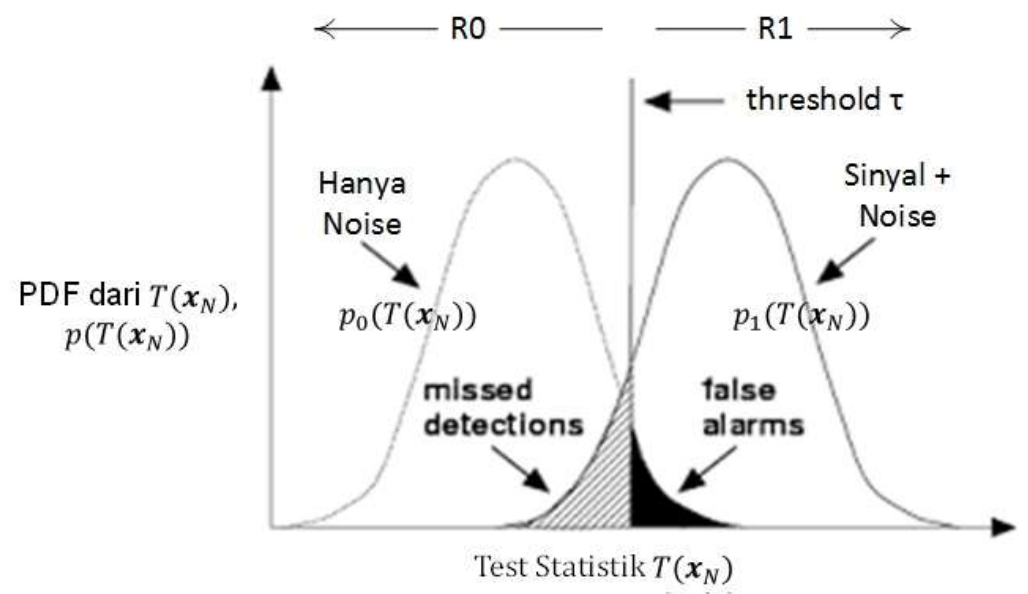

Gambar 1. PDF dari Test Statistic

Mengacu pada Gambar 1, kemungkinan untuk membuat errordalam memutuskan seperti pada Tabel 1, dapat didefinisikan kembali sebagai berikut:

Probability of False Alarm

$$
P_{f}=P\left(D_{1} / H_{0}\right)=P\left(T\left(\boldsymbol{x}_{N}\right)>\tau / H_{0}\right)=\int_{\tau}^{\infty} p\left(T\left(\boldsymbol{x}_{N}\right) / H_{0}\right) d T\left(\boldsymbol{x}_{N}\right)
$$

Probability of missed detection

$$
P_{m}=P\left(D_{0} / H_{1}\right)=P\left(T\left(\boldsymbol{x}_{N}\right)<\tau / H_{1}\right)=\int_{\tau}^{\infty} p\left(T\left(\boldsymbol{x}_{N}\right) / H_{1}\right) d T\left(\boldsymbol{x}_{\boldsymbol{N}}\right) .
$$

Sebagai catatan, tidak mungkin untuk mengurangi kedua error pada Persamaan (11) dan (12) secara bersamaan. Oleh sebab itu, untuk mendapatkan detektor sinyal yang optimal, pendekatan yang logis adalah membuat satu probabilitas error tetap dan meminimalkan probabilitas error yang lain.

Dalam paper ini ukuran kinerja yang digunakan adalah probability of false alarm dan probability of detection $\left(P_{d}\right)$, dimana

$$
P_{d}=1-P_{m}=\int_{\tau}^{\infty} p\left(T\left(\boldsymbol{x}_{N}\right) / H_{1}\right) d T\left(\boldsymbol{x}_{N}\right)
$$

Kriteria NP menyatakan bahwa sebuah detektor optimal jika test statistic $T\left(\boldsymbol{x}_{N}\right)$ dan threshold $\tau$ dipilih sehingga probability of missed detection $P_{m}$ minimum (probability of detection maksimum) dengan memberikan batasan probability of false alarm $P_{f}$ ditetapkan sebelumnya sama dengan harga nominal tertentu $P_{f}=\alpha$. Dengan menggunakan pendekatan Lagrange 
Multiplier sebagai solusi permasalahan optimasi, maka diperoleh bahwa test statistic untuk binary hypothesis testing pada persamaan (8) adalah likelihood ratio (Kay, 1998).

$$
T\left(\boldsymbol{x}_{N}\right)=\frac{p_{1}\left(\boldsymbol{x}_{N} ; \boldsymbol{\theta}_{\mathbf{1}}\right)}{p_{0}\left(\boldsymbol{x}_{N} ; \boldsymbol{\theta}_{\mathbf{0}}\right)} \begin{cases}>\tau, & \text { Terima } H_{1}\left(D_{1}\right) \\ <\tau, & \text { Terima } H_{0}\left(D_{0}\right)\end{cases}
$$

Dimana threshold $\tau$ ditentukan dari Persamaan (15).

$$
P_{f}=\int_{\tau}^{\infty} p\left(T\left(\boldsymbol{x}_{\boldsymbol{N}}\right) / H_{0}\right) d T\left(\boldsymbol{x}_{\boldsymbol{N}}\right)=\alpha .
$$

Detail penurunan menggunakan Lagrange Multiplier dapat dilihat di (Kay, 1998) untuk kasus satu detektor dan (Varshney, 1997) untuk banyak detektor.

Terdapat dua kasus umum pada metode deteksi sinyal dengan model parametrik. Jika parameter distribusi, yaitu $\boldsymbol{\theta}_{\mathbf{0}}, \boldsymbol{\theta}_{\mathbf{1}}$ atau keduanya diketahui maka disebut dengan simple hypothesis. Desain detektor sinyal menjadi lebih sulit ketika PDF mempunyai parameter yang tidak diketahui (unknown parameter). Kasus terakhir ini disebut dengan composite hypothesis. Bagian 4, Contoh Kasus Deteksi Sinyal, akan memberikan gambaran untuk memahami lebih lanjut kedua kasus tersebut.

\section{Generalized Likelihood Ratio Test (GLRT)}

Pada bagian sebelumnya, ketika menurunkan detektor optimal telah diasumsikan bahwa masing-masing PDF saat tidak ada sinyal $\left(H_{0}\right)$ dan ada sinyal $\left(H_{1}\right)$ diketahui secara menyeluruh (completely known). Dalam kenyataannya pendekatan tersebut bisa jadi tidak praktis, dimana satu atau lebih parameter distribusi tidak diketahui. Sebagai contoh pada deteksi target oleh radar, daya sinyal echo yang dipantulkan target dan diterima radar biasanya tidak diketahui. Demikian juga ketika derau diasumsikan terdistribusi Gaussian, tetapi variansi atau daya derau sulit untuk diketahui. Dengan kata lain, baik nullmaupun alternative hypothesis kedua-duanya termasuk kategori composite hypothesis. Oleh sebab itu, menjadi hal yang penting untuk mendesain detektor yang baik ketika PDF saat tidak ada sinyal $\left(H_{0}\right)$ dan ada sinyal $\left(H_{1}\right)$ tidak diketahui secara menyeluruh (incompletely known). Pada kasus ini, harus dilakukan pendekatan sub-optimum.

Salah satu pendekatan yang paling populer untuk composite hypotheses testing adalah Generalized Likelihood Ratio Test (GLRT). Konsep dari GRLT adalah mengganti semua parameter distribusi yang tidak diketahui dengan hasil estimasi masing-masing parameter tersebut menggunakan metode Maximum Likelihood Estimator (MLE) (Kay, 1993). Secara umum, GLRT mempunyai bentuk seperti pada Persamaan (16).

$$
T\left(\boldsymbol{x}_{\boldsymbol{N}}\right)=\frac{p_{1}\left(\boldsymbol{x}_{\boldsymbol{N}} ; \widehat{\boldsymbol{\theta}}_{\mathbf{1}}\right)}{p_{0}\left(\boldsymbol{x}_{\boldsymbol{N}} ; \widehat{\boldsymbol{\theta}}_{\mathbf{0}}\right)}\left\{\begin{array}{ll}
>\tau, & \text { Terima } H_{1}\left(D_{1}\right), \\
<\tau, & \text { Terima } H_{0}\left(D_{0}\right)
\end{array},\right.
$$

Dimana $\widehat{\boldsymbol{\theta}}_{\mathbf{0}}$ adalah MLE untuk parameter $\boldsymbol{\theta}_{\mathbf{0}}$ dengan asumsi $H_{0}$ adalah betul terjadi (true), sedangkan $\widehat{\boldsymbol{\theta}}_{\mathbf{1}}$ adalah MLE untuk parameter $\boldsymbol{\theta}_{\mathbf{1}}$ dengan asumsi $H_{1}$ adalah betul terjadi. MLE secara formal diperoleh dari Persamaan (17).

$$
\widehat{\boldsymbol{\theta}}_{\boldsymbol{i}}=\underset{\boldsymbol{\theta}_{\boldsymbol{i}}}{\arg \max } \ln \left(p_{i}\left(\boldsymbol{x}_{\boldsymbol{N}} ; \boldsymbol{\theta}_{\boldsymbol{i}}\right)\right) .
$$


Threshold $\tau$ ditentukan berdasarkan nominal probability of false alarm yang diinginkan $P_{f}=$ $\alpha$, seperti pada Persamaan (15).

\section{CONTOH KASUS DETEKSI SINYAL}

Pada bagian ini akan diberikan dua contoh cara untuk mendesain detektor dengan menggunakan pendekatan kriteria NP. Kasus pertama adalah jika distribusi diketahui secara menyeluruh (completely known) dan pada kasus kedua distribusi diketahui sebagian (partially known).

Dimisalkan terdapat permasalahan deteksi sinyal DC dengan amplitudo A pada derau Additive White Gaussian Noise (AWGN) yang dapat dituliskan pada Persamaan (18).

$$
\begin{aligned}
& H_{0}: x(n)=w(n) \\
& H_{1}: x(n)=A+w(n), \quad n=0,1,2, \ldots, N-1,
\end{aligned}
$$

Dimana $w(n)$ adalah terdistribusi Gaussian dengan mean dan variansi berturut-turut $\mu$ dan $\sigma^{2}$.

\section{Distribusi Diketahui}

Pada contoh ini diasumsikan amplitudo $A$, dimana $A>0$, dan variansi derau $\sigma^{2}$ keduanya diketahui. Sehingga pada saat tidak ada sinyal $x(n)$ akan terdistribusi Gaussian dengan mean $\mu=A=0$ dan variansi $\sigma^{2}$, sedangkan pada saat ada sinyal, $x(n)$ akan terdistribusi Gaussian juga dengan mean $\mu=A>0$ dan variansi $\sigma^{2}$. Permasalahan binary hypothesis menjadi :

$$
\begin{aligned}
& H_{0}: x \sim N\left(0, \sigma^{2}\right) \\
& H_{1}: x \sim N\left(A, \sigma^{2}\right) .
\end{aligned}
$$

Persamaan (19) menyatakan bahwa saat tidak ada sinyal $\left(H_{0}\right)$ maka parameter distribusi $\boldsymbol{\theta}_{\mathbf{0}}$ diketahui, yaitu $\left\{\mu=0, \sigma^{2}\right\}$, dan pada saat ada sinyal $\left(H_{1}\right)$ maka parameter distribusi $\boldsymbol{\theta}_{\mathbf{1}}$ diketahui yaitu $\left\{\mu=A, \sigma^{2}\right\}$. Sehingga nulldan alternative hypothesistermasuk kategori simple hypothesis (Poor, 1988).

Berdasarkan Persamaan (7) dan (14), dan menggunakan pendekatan kriteria NP, maka diperoleh likelihood ratio pada Persamaan (20).

$$
\frac{p_{1}\left(\boldsymbol{x}_{N} ; \boldsymbol{\theta}_{\mathbf{1}}\right)}{p_{0}\left(\boldsymbol{x}_{N} ; \boldsymbol{\theta}_{\mathbf{0}}\right)}=\frac{\frac{1}{\left(2 \pi \sigma^{2}\right)^{\frac{N}{2}}} \exp \left[-\frac{1}{2 \sigma^{2}} \sum_{i=0}^{N-1}(x(i)-A)^{2}\right]}{\frac{1}{\left(2 \pi \sigma^{2}\right)^{\frac{N}{2}}} \exp \left[-\frac{1}{2 \sigma^{2}} \sum_{i=0}^{N-1} x^{2}(i)\right]} \begin{cases}>\tau, & \text { Terima } H_{1}\left(D_{1}\right) \\ <\tau, & \text { Terima } H_{0}\left(D_{0}\right)\end{cases}
$$

Dengan mengambil logaritmik kedua sisi Persamaan (20) maka akan diperoleh Pesamaan (21).

$$
-\frac{1}{2 \sigma^{2}}\left(-2 A \sum_{i=0}^{N-1} x(i)+N A^{2}\right) \begin{cases}>\ln \tau, & \text { Terima } H_{1}\left(D_{1}\right) \\ <\ln \tau, & \text { Terima } H_{0}\left(D_{0}\right)\end{cases}
$$


Selanjutnya Persamaan (21) dapat disederhanakan menjadi Persamaan (22).

$$
-\frac{A}{\sigma^{2}} \sum_{i=0}^{N-1} x(i)\left\{\begin{array}{ll}
>\ln \tau+\frac{N A^{2}}{2 \sigma^{2}}, & \text { Terima } H_{1}\left(D_{1}\right) \\
<\ln \tau+\frac{N A^{2}}{2 \sigma^{2}}, & \text { Terima } H_{0}\left(D_{0}\right)
\end{array} .\right.
$$

Karena asumsi $A$ positif, maka dari Persamaan (22) akan diperoleh Persamaan (23).

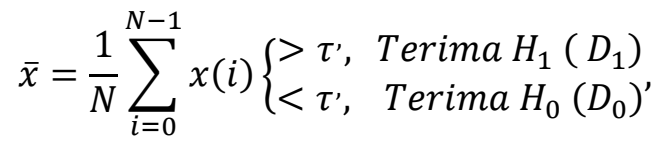

dimana threshold dinyatakan dengan Persamaan (24).

$$
\tau^{\prime}=\frac{\sigma^{2}}{N A} \ln \tau+\frac{A}{2}
$$

Detektor pada Persamaan (23) adalah detektor optimal untuk masalah binary hypothesis testing Persamaan (19). Optimal mempunyai pengertian untuk $P_{f}$ yang sama, tidak ada detektor lain yang akan menghasilkan $P_{d}$ yang lebih besar dari detektor pada Persamaan (23).

Dari persamaan (23) maka detektor membandingkan rata-rata sampel (sample mean) $\bar{x}$ dengan threshold $\tau$ '. Hal ini cukup logis karena PDF pada kedua hypothesis berbeda hanya pada mean ( 0 dan $\mathrm{A})$, dan $\bar{x}$ dapat dianggap sebagai estimator dari $A$. Jika hasil estimasi $\bar{x}$ besar dan positif maka sinyal DC kemungkinan besar ada. Besarnya harga hasil estimasi ketika memutuskan ada sinyal akan tergantung pada seberapa besar perhatian kita terhadap kemungkinan derau menghasilkan energi cukup besar yang akan menyebabkan keputusan salah (false alarm). Oleh sebab itu diperlukan mengatur threshold $\tau$ ' sehingga probability of false alarm $P_{f}$ dapat dikontrol. Threshold yang lebih besar akan menghasilkan $P_{f}$ yang lebih kecil, tetapi secara bersamaan akan memperkecil probability of detection $P_{d}$. Sehingga harus dicari hubungan antara $P_{d}$ terhadap $P_{f}$, yang disebut dengan kurva Receiver Operating Characteristics (ROC). ROC merupakan kurva yang sering digunakan untuk memperlihatkan dan membandingkan kinerja detektor.

Untuk menurunkan kinerja detektor secara analitis, diperlukan distribusi test statistic $T\left(\boldsymbol{x}_{N}\right)=$ $\bar{x}$ saat tidak ada sinyal $H_{0}$ maupun ada sinyal $H_{1}$. Karena $x(i), i=0,1,2, \ldots, N-1$ masing masing terdistribusi Gaussian dengan mean dan variansi yang sama, maka $T\left(\boldsymbol{x}_{\boldsymbol{N}}\right)$ yang merupakan penjumlahan variabel acak tersebut akan terdistribusi Gaussian saat $H_{0}$ dan $H_{1}$. Mean dan variansi dari distribusi $T\left(\boldsymbol{x}_{N}\right)$ saat $H_{0}$ dan $H_{1}$ harus ditentukan.

Saat tidak ada sinyal $H_{0}$, maka mean $\mu_{0}$ ditentukan dengan Persamaan (25)

$$
\mu_{0}=E_{0}\left\{T\left(\boldsymbol{x}_{\boldsymbol{N}}\right)\right\}=E_{0}\left\{\frac{1}{N} \sum_{i=0}^{N-1} x(i)\right\}=\frac{1}{N} \sum_{i=0}^{N-1} E_{0}\{w(i)\}=0 .
$$


Sedangkan saat ada sinyal $H_{1}$, mean $\mu_{1}$ dapat ditentukan dengan Persamaan (26).

$$
\mu_{1}=E_{1}\left\{T\left(\boldsymbol{x}_{N}\right)\right\}=E_{1}\left\{\frac{1}{N} \sum_{i=0}^{N-1} x(i)\right\}=E_{1}\left\{\frac{1}{N} \sum_{i=0}^{N-1} w(i)\right\}+E_{1}\left\{\frac{1}{N} \sum_{i=0}^{N-1} A\right\}=A,
$$

Dimana $E_{i}\{\cdot\}$ menyatakan ekspektasi dari variabel acak saat $H_{i}$ dan asumsi sampel-sampel dari derau independen. Sedangkan variansi saat tidak ada sinyal $\sigma_{0}^{2}$,

$$
\sigma_{0}^{2}=\operatorname{var}\left\{T\left(\boldsymbol{x}_{N}\right)\right\}=\operatorname{var}\left\{\frac{1}{N} \sum_{i=0}^{N-1} x(i)\right\}=\frac{1}{N^{2}} \sum_{i=0}^{N-1} \operatorname{var}\{w(i)\}=\frac{\sigma^{2}}{N}
$$

Saat ada sinyal :

$$
\sigma_{1}^{2}=\operatorname{var}\left\{T\left(\boldsymbol{x}_{N}\right)\right\}=\operatorname{var}\left\{\frac{1}{N} \sum_{i=0}^{N-1} x(i)\right\}=\frac{1}{N^{2}} \sum_{i=0}^{N-1} \operatorname{var}\{A\}+\frac{1}{N^{2}} \sum_{i=0}^{N-1} \operatorname{var}\{w(i)\}=\frac{\sigma^{2}}{N}
$$

Oleh sebab itu, maka distribusi test statistic $T\left(\boldsymbol{x}_{N}\right)$ dapat dinyatakan dengan Persamaan (29).

$$
T\left(\boldsymbol{x}_{N}\right)\left\{\begin{array}{l}
N\left(0, \frac{\sigma^{2}}{N}\right) \text { saat } H_{0} \\
N\left(A, \frac{\sigma^{2}}{N}\right) \text { saat } H_{1}
\end{array}\right.
$$

Dengan demikian probability of false alarm $P_{f}$ dihitung dari distribusi $T\left(\boldsymbol{x}_{N}\right)$ saat tidak ada sinyal dinyatakan dengan Persamaan (30).

$$
P_{f}=P_{0}\left(T\left(\boldsymbol{x}_{N}\right)>\tau^{\prime}\right)=\int_{\tau^{\prime}}^{\infty} p_{0}\left(T\left(\boldsymbol{x}_{N}\right)\right) d T\left(\boldsymbol{x}_{N}\right)=Q\left(\frac{\tau^{\prime}}{\sqrt{\sigma^{2} / N}}\right),
$$

Dimana fungsi $Q(\cdot)$ adalah Complementary Cumulative Distribution Function (CCDF) untuk distribusi normal $N(0,1)$ dinyatakan dengan Persamaan (31).

$$
Q(x)=\int_{x}^{\infty} \frac{1}{\sqrt{2 \pi} x} \exp \left(-\frac{1}{2} x^{2}\right)
$$

Sedangkan untuk menentukan probability of detection $P_{d}$ dihitung dari distribusi $T\left(\boldsymbol{x}_{\boldsymbol{N}}\right)$ saat ada sinyal menggunakan Persamaan (32).

$$
P_{d}=P_{1}\left(T\left(\boldsymbol{x}_{N}\right)>\tau^{\prime}\right)=\int_{\tau^{\prime}}^{\infty} p_{1}\left(T\left(\boldsymbol{x}_{N}\right)\right) d T\left(\boldsymbol{x}_{N}\right)=Q\left(\frac{\tau^{\prime}-A}{\sqrt{\sigma^{2} / N}}\right) .
$$

Hubungan antara $P_{d}$ dan $P_{f}$ dapat ditentukan dari Persamaan (29) dan (31). Karena fungsi $Q$ adalah monoton turun, maka fungsi $Q$ mempunyai inverse yang disimbolkan dengan $Q^{-1}$. 
Berdasarkan Persamaan (30), threshold dapat ditentukan dengan Persamaan (33).

$$
\tau^{\prime}=\sqrt{\frac{\sigma^{2}}{N}} Q^{-1}\left(P_{f}\right)
$$

Setelah disubstitusi ke Persamaan (32), maka akan diperoleh Persamaan (34).

$$
P_{d}=Q\left(\frac{\sqrt{\frac{\sigma^{2}}{N}} Q^{-1}\left(P_{f}\right)-A}{\sqrt{\sigma^{2} / N}}\right)=Q\left(Q^{-1}\left(P_{f}\right)-\sqrt{\frac{N A^{2}}{\sigma^{2}}}\right)
$$

Persamaan (34) menyatakan hubungan antara $P_{d}$ dan $P_{f}$ (kurva ROC). Sebagai catatan, penurunan kinerja detektor dengan kurva ROC secara analitis tidak selalu dapat dilakukan. Hal ini tergantung apakah bentuk tertutup (closed form) PDF dari test statistic dapat ditentukan atau tidak, baik secara eksak ataupun asymptotic menggunakan central limit theorem (Serfling, 2009). Apabila PDF tidak dapat ditentukan secara tertutup maka kinerja detektor dapat dievaluasi dengan cara simulasi Monte Carlo (Suratman, 2010).

\section{Distribusi Diketahui Sebagian}

Selanjutnya, akan dipertimbangkan masalah binary hypothesis testing pada Persamaan (19) dengan kondisi dimana amplitudo $A \neq 0$ dan tidak diketahui, sedangkan variansi noise $\sigma^{2}$ diketahui. Permasalahan ini dapat dipecahkan dengan GLRT, dimana amplitudo $A$ harus diestimasi terlebih dahulu dengan menggunakan MLE.

Berdasarkan Persamaan (17) MLE dari amplitudo $A$ adalah dengan memaksimalkan fungsi loglikelihood PDF saat ada sinyal $H_{1}$, sehingga diperoleh Persamaan (35).

$$
\ln p_{1}\left(\boldsymbol{x}_{N} ; A\right)=\ln \left(\frac{1}{\left(2 \pi \sigma^{2}\right)^{\frac{N}{2}}} \exp \left[-\frac{1}{2 \sigma^{2}} \sum_{i=0}^{N-1}(x(i)-A)^{2}\right]\right)
$$

Harga A yang memaksimalkan fungsi Persamaan (35) dapat dicari dengan menurunkan fungsi tersebut terhadap $A$ dan ditentukan sama dengan nol, seperti pada Persamaan (36).

$$
\frac{\partial \ln p_{1}\left(x_{N} ; A\right)}{A}=\frac{1}{\sigma^{2}} \sum_{i=0}^{N-1}(x(i)-A)=0,
$$

Maka $\hat{A}$ sebagai MLE dari parameter $A$ akan diperoleh sama dengan mean sampel $\bar{x}$ melalui Persamaan (37).

$$
\hat{A}=\bar{x}=\frac{1}{N} \sum_{i=0}^{N-1} x(i)
$$

Kita tidak perlu melakukan estimasi parameter dari PDF saat tidak ada sinyal $H_{0}$, karena semua parameter distribusi telah diketahui yaitu $\mu=0$ dan variansi $\sigma^{2}$. 
Selanjutnya detektor dicari dengan menggunakan GLRT, yaitu menggunakan Persamaan (38).

$$
\frac{p_{1}\left(\boldsymbol{x}_{N} ; \hat{A}\right)}{p_{0}\left(\boldsymbol{x}_{N}\right)}=\frac{\frac{1}{\left(2 \pi \sigma^{2}\right)^{\frac{N}{2}}} \exp \left[-\frac{1}{2 \sigma^{2}} \sum_{i=0}^{N-1}(x(i)-\bar{x})^{2}\right]}{\frac{1}{\left(2 \pi \sigma^{2}\right)^{\frac{N}{2}}} \exp \left[-\frac{1}{2 \sigma^{2}} \sum_{i=0}^{N-1} x^{2}(i)\right]}\left\{\begin{array}{l}
>\tau, \text { Terima } H_{1}\left(D_{1}\right) \\
<\tau, \quad \text { Terima } H_{0}\left(D_{0}\right)
\end{array}\right.
$$

Dengan menerapkan logaritma pada kedua sisi Persamaan (38) maka akan diperoleh Persamaan (39).

$$
-\frac{1}{2 \sigma^{2}}\left(\sum_{i=0}^{N-1} x^{2}(i)-2 \bar{x} \sum_{i=0}^{N-1} x(i)+N \bar{x}^{2}-\sum_{i=0}^{N-1} x^{2}(i)\right) \begin{cases}>\ln \tau, & \text { Terima } H_{1}\left(D_{1}\right) \\ <\ln \tau, & \text { Terima } H_{0}\left(D_{0}\right)\end{cases}
$$

Setelah dilakukan penyederhanaan terhadap Persamaan (39) akan diperoleh Persamaan (40).

$$
-\frac{1}{2 \sigma^{2}}\left(-2 N \bar{x}^{2}+N \bar{x}^{2}\right)\left\{\begin{array}{ll}
>\ln \tau, & \text { Terima } H_{1}\left(D_{1}\right) \\
<\ln \tau, & \text { Terima } H_{0}\left(D_{0}\right)
\end{array} .\right.
$$

Sehingga, test statistic dapat ditulisakan sebagai Persamaan (41).

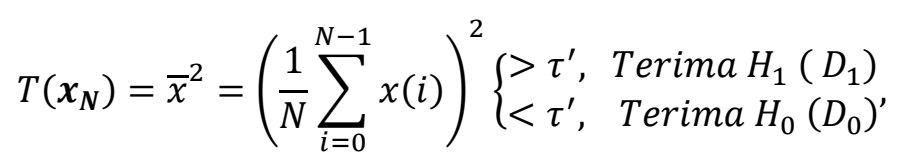

Dimana $\tau^{\prime}=\frac{2 \sigma^{2}}{N} \ln \tau$. Test statistic $T\left(\boldsymbol{x}_{N}\right)$, dapat juga dituliskan sebagai Persamaan (42).

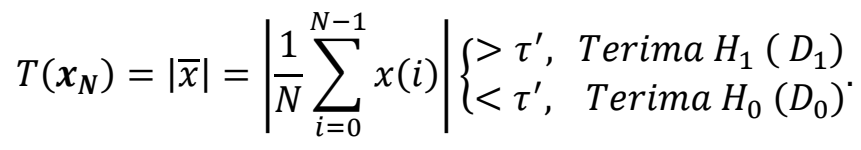

Distribusi (PDF) dari test statistic $T\left(\boldsymbol{x}_{\boldsymbol{N}}\right)$ saat tidak ada sinyal $H_{0}$ dan ada sinyal $H_{1}$ dapat diturunkan, seperti yang telah dicontohkan pada kasus distribusi diketahui seluruhnya. Berdasarkan kedua distribusi tersebut, akan diperoleh persamaan kurva ROC secara analitis menggunakan Persamaan (43) (Kay, 1998).

$$
P_{d}=Q\left(Q^{-1}\left(\frac{P_{f}}{2}\right)-\sqrt{\frac{N A^{2}}{\sigma^{2}}}\right)+Q\left(Q^{-1}\left(\frac{P_{f}}{2}\right)+\sqrt{\frac{N A^{2}}{\sigma^{2}}}\right)
$$

\section{HASIL SIMULASI}

Bagian ini akan menunjukkan kinerja detektor yang telah dijelaskan pada bagian 4, yaitu untuk kasus distribusi diketahui menyeluruh menggunakan test statistic Persamaan (21). Ada dua tujuan utama dari simulasi ini. Pertama adalah menunjukkan bahwa kinerja detektor yang diturunkan secara analitis pada Persamaan (34) dan dengan simulasi Monte Carlo (MC), akan menghasilkan kinerja serupa. Kedua, menunjukkan pengaruh dua parameter penting yaitu Signal to Noise Ratio (SNR) dan jumlah sampel $N$ terhadap kinerja detektor. SNR dalam 
simulasi ini didefinisikan sebagai $S N R=10 \log _{10}\left(\frac{A^{2}}{\sigma^{2}}\right)$, dimana daya noise ditetapkan $\sigma^{2}=1$ untuk keseluruhan simulasi. Hasil simulasi diperoleh dengan melakukan pengulangan Monte Carlo sebanyak 1000 kali. Kurva akan semakin mendekati hasil analitis jika pengulangan Monte Carlo diperbanyak. Pengulangan 1000 kali sengaja diambil agar hasil simulasi dan analitis dapat dibedakan secara visual.

Gambar 2.a menunjukkan distribusi test statistic Persamaan (23) saat tidak ada sinyal $\left(H_{0}\right)$ dan ada sinyal $\left(H_{1}\right)$, baik secara analitis pada Persamaan (29) maupun dengan simulasi MC. Gambar tersebut memperlihatkan distribusi test statistic secara analitis dan simulasi mempunyai hasil serupa. Ketika SNR naik, distribusi test statistic saat $H_{1}$ akan bergeser menjauh ke sebelah kanan dari distribusi test statistic saat $H_{0}$. Sehingga kinerja detektor berupa probability of detection, untuk probability of false alarm tertentu, akan semakin membaik (membesar), seperti yang ditunjukkan Gambar 2.(b).

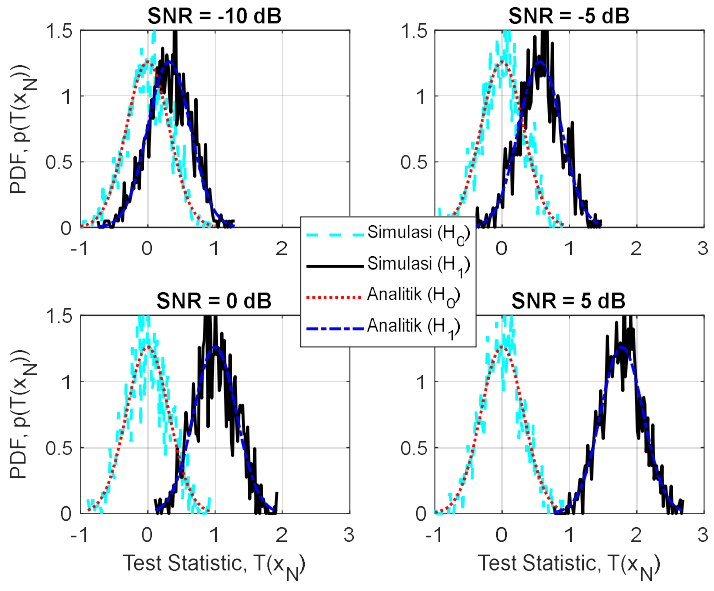

(a)

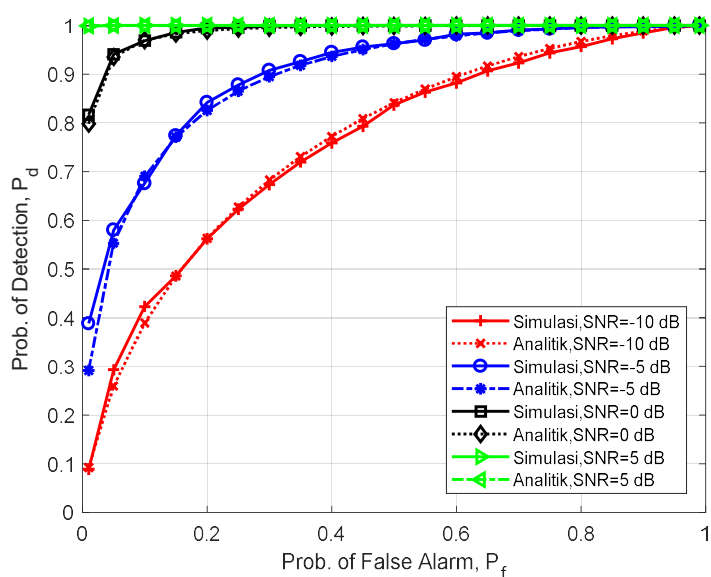

(b)

Gambar 2. (a) PDF dari Test Statistic (b) Kurva Receiver Operating Characteristics (ROC) sebagai Parameter Kinerja untuk Nilai SNR yang Berbeda

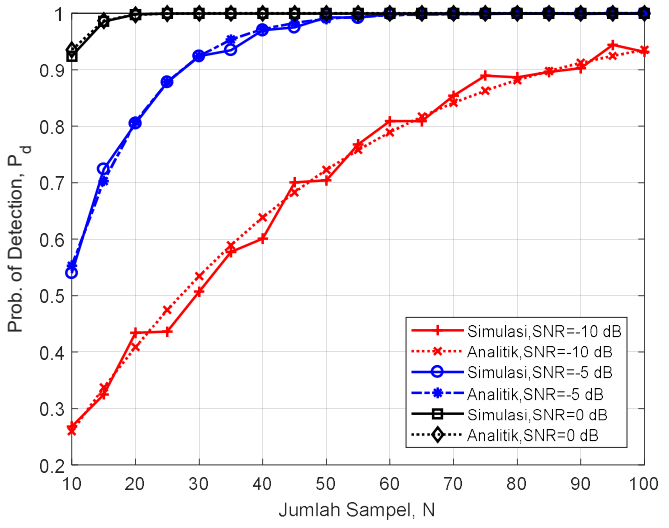

(a)

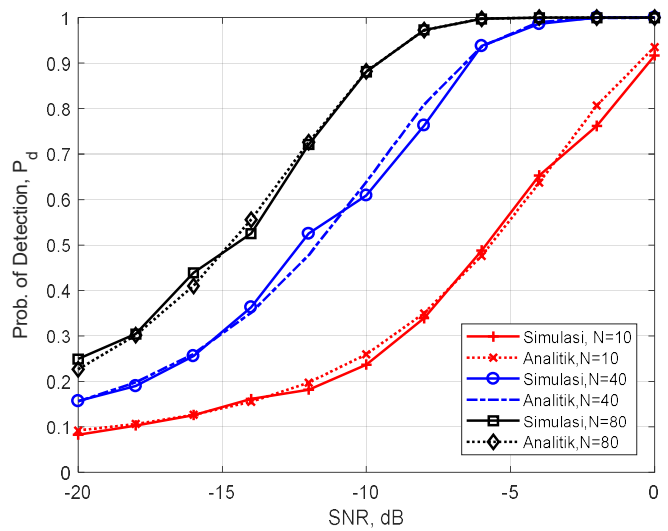

(b)

Gambar 3. Kinerja Detektor dengan Parameter Probability of Detecion $P_{d}$ (a) sebagai Fungsi Jumlah Sampel N (b) sebagai Fungsi SNR 
Kinerja detektor sebagai fungsi dari jumlah sampel $\mathrm{N}$ untuk SNR yang berbeda ditunjukkan pada Gambar 3.a. Sesuai dengan dugaan bahwa jumlah sampel N semakin besar maka kinerja detektor dengan parameter probability of detection akan semakin naik. Karena dengan sampel yang semakin banyak detektor mempunyai jumlah informasi yang lebih banyak untuk mengambil keputusan secara benar berdasarkan observasi yang dilakukan. Sedangkan Gambar 3.b. menunjukkan probability of detection semakin baik untuk SNR yang semakin besar, karena daya sinyal semakin dominan dibandingkan dengan daya derau. Hal tersebut memberikan kemudahan untuk detektor dalam menentukan keberadaan sinyal yang diinginkan bersama derau. Kedua gambar dihasilkan dengan probability of false alarm diset $P_{f}=0,05$. Karena terbatasnya halaman paper ini, hasil simulasi kinerja detektor dengan distribusi diketahui sebagian bisa didapat dari lampiran suplemen yang dapat diminta melalui email ke penulis pertama.

Catatan. Paper ini merupakan penjelasan sebagian kecil dari teori deteksi yang sudah banyak berkembang, yang didukung oleh perkembangan teori statistik, terutama menyangkut hypothesis testing. Banyak metode untuk deteksi sinyal selain menggunakan pendekatan Neyman-Pearson, misalkan dengan pendekatan statistik Bayesian (Varshney, 1998). Pada kasus deteksi sinyal untuk kondisi SNR yang sangat kecil dapat digunakan metode Locally Optimum Detection (Kassam, 1988)(Suratman, 2010). Banyak kasus dimana distribusi dari test statistic tidak dapat ditentukan dalam bentuk tertutup, sehingga bergantung dengan statistik aproksimasi, misalkan dengan teorema central limit atau teorema large number (Serfling, 2009). Tetapi untuk jumlah sampel yang kecil, hasil analitis pendekatan statistik aproksimasi akan berbeda cukup jauh dari hasil simulasi. Untuk mengatasi hal tersebut dapat digunakan Bootstrapping (Zoubir, 2004). Bootstrapping juga dapat dilakukan untuk deteksi sinyal secara adaptif, tidak bergantung pada asumsi distribusi sinyal yang digunakan (Suratman, 2013). Teori deteksi sekuensial dimana jumlah sampel dibuat random dapat dilihat pada (Suratman, 2014). Deteksi sekuensial diturunkan berdasarkan teorema sequential analysis (Wald, 1945). Deteksi sekuensial mempunyai dua keuntungan, yaitu: Probability of false alarm dan miss detection dapat dikontrol sekaligus pada saat bersamaan, dan menghasilkan jumlah rata-rata sampel yang lebih kecil dibanding metode Neyman-Pearson dengan jumlah sampel tetap. Deteksi sinyal dapat juga dilakukan secara kolaboratif oleh banyak detektor secara bersamaan yang disebut dengan deteksi terdistribusi (distributed detection). Cara tersebut dapat dilihat di (Varshney, 1998) dan (Suratman, 2011). Deteksi sinyal yang menggabungkan teknik sekuensial dan multiple testing procedure yang diimplementasikan untuk multiband spectrum sensing dapat dilihat di (Suratman, 2014).

\section{KESIMPULAN}

Overview mengenai deteksi sinyal menggunakan model parametrik Neyman-Pearson dipresentasikan pada paper ini. Contoh penurunan metode Neyman-Pearson untuk desain test statistic telah diberikan dengan menggunakan model distribusi Gaussian dengan skenario kondisi distribusi diketahui penuh dan diketahui sebagian. Hasil eksperimen kinerja detektor secara analitis dan simulasi telah diperlihatkan dan menunjukkan kinerja yang serupa. Diharapkan paper ini dapat dijadikan sebagai dasar bagi para peneliti maupun mahasiswa yang tertarik untuk mempelajari teori deteksi sinyal untuk berbagai aplikasi. Teori deteksi sinyal yang lebih kompleks dapat ditemukan pada referensi-referensi yang dicantumkan pada paper ini. 


\section{DAFTAR RUJUKAN}

Axell, E., Leus, G., Larsson, E.G., \& Poor, H.V. (2012). Spectrum sensing for cognitive radio: State-of-the-art and recent advances. IEEE Signal Processing Magazine, 29(3), 101116.

Garcia, R.L. (1994). Probability and Random Processes for Electrical Engineering. AddisonWesley Publishing Company.

Gibson, J.D. \& Melsa, J.L. (1996). Introduction to nonparametric detection with applications. New York: IEEE Press.

Hossain, E., Niyato, D., \& Han, Z. (2009). Dynamic Spectrum Access and Management in Cognitive Radio Networks. Cambridge University Press.

Kassam, S.A. (1988).Signal detection in non-Gaussian noise. Springer-Verlag.

Kay, S.M. (1993). Fundamentals of Statistical Signal Processing: Estimation Theory. Prentice Hall, Inc.

Kay, S.M. (1998). Fundamentals of Statistical Signal Processing: Detection Theory. Prentice Hall, Inc.

Poor, V.H. (1988). An introduction to signal detection and estimation. Springer-Verlag.

Richards, M.A (2014). Fundamentals of Radar Signal Processing. New York: McGraw Hill Education.

Serfling, R.J. (2009) Approximation theorems of mathematical statistics. John Wiley \& Sons, Inc.

Suratman, F.Y., Chakhchoukh, Y., \& Zoubir, A.M. (2010). Locally Optimum Detection in HeavyTailed Noise for Spectrum Sensing in Cognitive Radio. The 2nd International Workshop on Cognitive Information Processing (CIP), (pp. 134-139).

Suratman, F.Y. and Zoubir, A.M. (2013). Bootstrap Based Sequential Probability Ratio Tests. The IEEE International Conference on Acoustics, Speech and Signal Processing (ICASSP), (pp. 6352-6356).

Suratman, F.Y. \& Zoubir, A.M. (2014). Multiple Testing for Sequential Probability Ratio Tests with Application to Multiband Spectrum Sensing, in The IEEE International Conference on Acoustics, Speech and Signal Processing (ICASSP), (pp. 3444-3448).

Wald, A. (1945). Sequential tests of statistical hypotheses. The Annals of Mathematcal Statistics.(pp.117-186).

Varshney, P.K. (1997) Distributed detection and data fusion. Springer.

Zoubir, A.M. (2004). Bootstrap techniques for signal processing. Cambridge University Press. 